\title{
The Practice of Practice
}

\author{
Heather Horst, David Morley, and Noel B. Salazar \\ in Conversation with Roger Norum
}

This conversation considers some of the disciplinary divides and anxieties surrounding contemporary research on media and mobility through a discussion of linkages between these two research fields and the role of non-media centric focuses on media across the disciplines. The conversation was sparked by the three-day workshop, Anthropologies of Media and Mobility: Theorizing Movement and Circulations across Entangled Fields, held in September, 2017 at The University of Cologne. ${ }^{1}$ One of the coconvenors Roger Norum sat down with a trio of leading scholars working on media and mobility, Heather Horst, David Morley, and Noel B. Salazar. They address a number of critical topics such as the nature of binary and category disruption, contextually dependent forms of media, the value of collaborative scholarship, the roles of methodologies in academic practice and the critical role played by early-career researchers in pushing various boundaries across our fields.

Roger Norum: Since you all come from somewhat diverse disciplinary backgrounds and research focuses, I wondered if we might start off, just by way of introduction, for you to each talk a bit about what sorts of things you work on, or how you came into the kind of research you do.

Heather Horst: I have been working in Australia for six or so years after having been in the US and UK. The bulk of my work has been most recently focused on the Global South - I worked in the Caribbean and also in the Pacific. One of my current projects is on the cultural history of mobile phones in the Pacific since globalization, comparing Fiji and Papua New Guinea. I work with colleagues at

1 The event was sponsored by the Anthropology and Mobility Network (ANTHROMOB) and the Media Anthropology Network of the European Association of Social Anthropologists (EASA), in collaboration with a.r.t.e.s. Graduate School for the Humanities and CA IV - Cultures and Societies in Transition (University of Cologne), and the DFG Research Training Group Locating Media and SFB Media of Coorporation (University of Siegen). 
the Digital Ethnography Research Centre at $\mathrm{RMIT}^{2}$ on data and locative technologies and their use in families, considering, in part, how people are relating to digital and material storing.

David Morley: As a recovering sociologist, I teach cultural geography in a department of media and communication studies. I'm not in any discipline that entirely fits or suits, as a result of having gone through a cultural studies education and learning how much could be gained from different perspectives along the way. And somewhere along that route I stumbled into anthropologists who seemed to be doing quite interesting things as far back as the mid-8os, when I first came across people like Danny Miller and Mark Hobart in London, who were beginning to understand that anthropology had a business to conduct with the contemporary world, not just the traditional world. And that was quite contentious, because at that point there were other people in anthropology in the UK who actually argued that cultural studies was rubbish, that anthropology was the only discipline that understood culture, and that it had no business getting caught up in all this kind of popular media stuff. Happily, we're well past all of this now, I think. These days, I read probably more anthropology than sociology, I certainly don't read much media or communication studies as it has become very media-centric and very technologically focused. The "new mobilities" stuff was something I wandered into it from the side from a contact with John Urry, and that very much informed my work in the recent period. I've just written this book that discusses three emblems of modernity and mobility. ${ }^{3}$

Noel B. Salazar: I'm an anthropologist, although I also have other degrees - but most people know me as an anthropologist. I got interested in mobility almost by force. I was doing research on tourism and when I moved to my current research unit, there was nobody doing research on tourism and I had to fit in. The majority of my colleagues were doing research on migration. And so I was thinking of ways in which I could link migration and tourism, which wasn't all that difficult - and mobility was an interesting way to actually do this. ${ }^{4}$ Out of those exercises, I became very interested in doing a little meta-scholarly work on the kind of discourse we use as scholars when we talk about the things we study. ${ }^{5}$

RN: It is reassuring to know that I am not alone in my disciplinary anxieties! I came out of a very traditional, "classical" social anthropology department, where I had developed an interest in human migration. My doctoral supervisor was at

2 See https://www.rmit.edu.au/research/research-institutes-centres-and-groups/re search-centres/digital-ethnography-research-centre.

3 See Morley (2017).

4 See http://soc.kuleuven.be/immrc/cumore.

5 See Salazar/Jayaram (2016) and Salazar/Coates (2017). 
first somewhat dismissive of this interest - he didn't seem to think that studying migration was "proper" anthropology. He suggested I move across the road, literally, to pursue this interest at a migration studies centre, which I eventually did. But once there, I found I was interested less in so-called traditional forms of migration and more in the multiple mobilities of people from the Global North elsewhere. So, after already feeling a bit ex-communicated disciplinarily from social anthropology, I once again became a sort of disciplinary black sheep, since most people working in or on migration studies at the time was studying migration as the social sciences most commonly define it. And then, what happens? A few years later, I end up getting a job as a postdoc in an English literature department - of all places - working on a big interdisciplinary project with geographers and cultural studies scholars. I wonder how important one's disciplinary dogma or institutional affiliation is in how one approaches studying media. Do we all need to think of ourselves as always, already post-disciplinary, or can there be value in sticking to one gun, as it were? Or perhaps we are all just destined to become black sheep.

HH: I think you need to understand the various lineages and what the stakes are, for example, to know when you're overstepping boundaries and to know when to stay within them. I still always identify as an anthropologist, but the way I go about that type of work differs depending on the kind of project I am working on. When I am working with more cultural studies scholars, for example, I tend to bring to a research project more of the analytical rigor of what an anthropologist typically would. In my political commitments, too, I am very much in favour of studying some of the contexts that anthropologists traditionally have done. So that dialectic between different disciplines is quite important.

DM: I think there is value in a staged operation. At Goldsmiths, we offer an interdisciplinary degree in media and communications. I am very invested in interdisciplinary work, but I do think that you have to know one discipline thoroughly before you can move into actually doing interdisciplinary work. You do need to get out of your discipline, but you also need to have been there.

NS: Disciplines were historically created for certain reasons related to power in academia - in order to craft yourself a space and also get a piece of the financial pie. And so, whether we like or dislike disciplines, they will be here for some time because of these vested interests. Most people agree that there are issues with all these sometimes very arbitrary disciplinary divides, but they are not going away anytime soon thanks to these issues of power and capital. Having said that, it is quite important when you start in academia that you are confronted with a coherent set of authors and ideas. And once you have that, then you should have the freedom to move on and add all kinds of things to it. There's also a huge confusion of terms with respect to disciplinarity: we have inter-disciplinarity, multi- 
disciplinarity, trans-disciplinarity, cross-, post-, etc. At the same time, when you move out of your discipline you become quite aware of how much you have been brainwashed, how much your discipline "moves" you in a certain direction. This also makes the contact between disciplines difficult because you think that you speak the same language but you don't - even if you might use the same concepts. That is what I find interesting about the media scholars I engage with: many of them are anthropologists, and many of them use the same terms, such as "media" or "mobility", but it's very clear from how they use the terms that they understand them in different ways. Nobody sees the need to define terms but I think if you asked a number of people to define the key terms they work with, you would see that there are some real differences between them.

DM: This is why I often tend to use definitions of a historical kind, such as from the Oxford English Dictionary. I do this precisely because of the politics of my work: I am very keen to disrupt the reduction of communication to the notion of semiotic systems, which is what has happened in media and communications in the UK and the US. For example, in my book I insist on the notion of transport as a dimension of communication - that there are bodies and things being moved within around and through infrastructures - an ideal which has only very belatedly gotten any traction. The only way you can actually disrupt is to hit at the very definitions. Like: hey folks, everybody seems to mean this but shouldn't we also mean that? I hope that this is a productive move.

RN: That questioning of binaries and categories, and indeed terms themselves, is one thing that anthropological thinking encourages: you don't necessarily look at what is; you look at how what is is framed and discussed and categorized, and then you can better understand how and why what is is, and why who says what is is. There have continued to be calls for more work that takes a non-media centric focus on media - which if you're interested in discursivity and epistemic categories can be quite an interesting take on a phenomenon. Where would you say this has come from epistemically?

DM: When I first got hired at Goldsmiths, I was interviewed for a job as lecturer in television studies. I hadn't quite taken on board that they were actually serious about that. My first response was, "I'm not interested in television studies - television studies alone doesn't make any sense!” At that time, I was trying to reframe that as something broader, such as screen studies or audio-visual studies or something similar. Similarly, all the "new media" debate in the UK proceeds as if these things are so powerful that we no longer need old media studies, the sense is that we need digital media studies, or that we're going to start from the year zero in order to understand the digital. No, no, no, we're not. Lynn Spigel has written that if you want to understand futurology, you've got to have an historical perspective 
on it. ${ }^{6}$ That took me back to the notion that what we needed was a non-media centric media studies, a materialist version of an idea of communication. That was how I responded to what I saw as a set of emerging difficulties and limitations in the work that was coming across in the field.

RN: For someone coming to media studies from another discipline, though, the term "non-media centric media" sounds at first curious and odd. Like a nonethnographic ethnography, or a post-ontological turn ontology. What I appreciate about this idea of looking at media beyond media - processes beyond states, or materialities beyond objects - is that it compels you to step back and question implicit presumptions in how you define your work. And you then come to see that these basic tenets are really much more complex then we tend to give them credit for.

NS: It's interesting because there were very similar developments in this whole field of mobility, too. One of these points of entry was transport. Historically in that field all the experts were experts in a certain means of transport. So you had researchers focusing on train travel and others concerned with car transport, for example. This was all very separated and there were not many people looking at the connections, or what is the broader scheme. The fact that there were all these people looking from these various angles has actually provoked and opened things up, helped show the complexity of it all. In order to understand something very specific, it is very worthwhile to also know the whole context around it.

HH: My background is material culture studies - I've done work on migration and material culture of the house. So if anything, my work would get critiqued for privileging the social over other things, in part because of books like The Cell Phone, or Digital Anthropology or Digital Ethnography. In a certain way, my encounter with looking at the specificity of media and their possibilities - whether or not we want to talk about affordances - and what people do with them, that what I privilege. So in a way, taking it back a step and seeing media and digital media as part of material culture is part of that same process of putting it on equal terms, at least from an analytical perspective. It's important to be able to say: ok, these are the relationships that people have with things. And then you have work by Alfred $\mathrm{Gell}^{8}$ and others who looked at what happens when objects take on a life of their own or move with or without the intent of a person. The Social Life of Things ${ }^{9}$ is a classic, and I'm still kind of back there in a certain way because that perspective has actually been quite important. So if anything, my challenge is to look at how

6 See Spigel (2004).

7 Horst/Miller (2006), Horst/Miller (2012), Pink et al. (2016).

8 See Gell $(1986 ; 1998)$.

9 See Appadurai (1986). 
much I have taken digital media seriously on its own terms without defaulting to a cultural or social explanation for everything, and pushing myself to really look at that dialogue. And that's where a lot of the work on infrastructure is interesting for disrupting that a little bit and forcing you to play. This moves The Social Life of Things and material culture studies in a productive direction. Whether it's mobility, media or even anthropology that you're coming from, how you can push those categories becomes really quite interesting.

DM: I think there is also a geography to this in terms of what is productive in which particular situation. Help can come from very unlikely circumstances and directions. I remember one of the first times I came to Germany in the late 1980 s, I was invited to Tübingen, a very traditional university which has a department of Folklore Studies. What could be more traditional - this was not even Anthropology, this was Folklore Studies! It turned out that they were hosting an American media scholar, Ellen Seiter, who was doing a study of international soap operas and their audiences. ${ }^{10}$ Most media scholars in Germany wanted nothing to do with the project because as far as they were concerned, this had to do with trash popular culture - which a serious academic institution had no business with. But there was this one guy in Tübingen called Hermann Bausinger, a Professor of Folkloric Studies, who had in fact been doing fantastic media work. He'd written in the late 1960 s a book called Folk Culture in a World of Technology, and he'd completely demolished that opposition between anthropology - you know, tradition and ritual - and technology - thought of as all science and rational thinking. ${ }^{11}$ And this was in the late 6os, and he was doing it in the context of something that still had among its formal protocols a devotion to folkloric studies. It's just that he managed to redefine what "folkloric" meant. So from that point of view the mobile phone is a part of folklore - what's the problem? Why not? It astounded me that was where we could find a kind of sympathetic, international conversation about cultural studies and technology - in the most hide-bound of the German universities, in the most old-fashioned department - where somebody had turned it on its head.

RN: I'm all for turning things on their heads, and it's great to come across a scholar you never heard of before who really makes you see things with new lenses. One reason I love being involved in championing the work of doctoral students, having only recently moved on from being one myself, is that they are often the ones doing some of the most interesting work. Being unaware of some of the epistemic or disciplinary divides that have long been out there - to say nothing of the social or cultural ones - can make it really easy to just see beyond them. When it comes to work on media, this is evermore the case. And of course, there are now students

10 See Seiter et al. (1989).

11 Bausinger (1990[1961]). 
in undergraduate, Master's and doctoral programmes for whom "new" media is anything but new.

NS: Isn't it sad that innovation often only comes from new people? I totally agree that of course young people have and will push boundaries. A PhD student of mine who defended last year started off with this project that looked at how new communication media impacted on the Maasai - that was her starting premise. But when she arrived in Maasailand (Tanzania), she actually turned things all around and discovered that there's nothing new there, and that the way in which the Maasai are using these new technologies is just a continuation of how they have been using older technologies. ${ }^{12}$ And so there's nothing like a rupture or a breaking, but rather many lines of continuation. It's definitely an insight that changed her and her perspective, and it's an important message to bring to our different fields. I also hope that one of the things that will help us is the mobility of scholars, by moving scholars around and being confronted with different frameworks and different ways of thinking, that this will also help us to come to new insights.

HH: I've been working in this digital media and learning space for a number of years, thinking about how young people are creating and innovating and recognizing new forms of informal learning, particularly within the context of privatization of public education. One student I co-supervise has been doing some work on digital media learning in Trinidad, studying how the ideas behind what education is considered to be there - MOOCs, for example - are often coming from the Global North as part of national development strategies. She was a policymaker before doing her $\mathrm{PhD}$, and now she is looking, in part, at how the practices of education are embedded in a colonial system. One of the things she brings up in her work is this notion of social confidence, where adults in Trinidad are going on YouTube in the privacy of their own home. To become proficient at things, they are studying online tutorials so that when they get into a classroom or an educational setting, they won't be shamed when they don't know the answer. So these concepts about learning, and what is the right way to learn, what digital media can do for learning - it can be really interesting if you start to look at how these ideas circulate and how these local contexts shake these things up. Not that the project is to disrupt or take on every kind of conceptual issue that comes from the Global North, but for me there is a very important need to do the kind of empirical, grounded research that is in dialogue with a lot of these things. I have a feeling that that context is not dissimilar to what is happening in a number of other places. I'm interested in the traveling concepts and looking at innovation and learning, and at those sorts of things that are becoming inscribed into different people's practices. That is also a productive way to look at some of these changes going on. I think lot of ideas are spreading pretty uncritically at lots of moments.

12 See Nilsson/Salazar (2017). 
DM: I described myself as a sort of a recovering sociologist, but I haven't recovered completely and nor do I want to. One of the things that I've been thinking about is the reinvigoration of what was once an offshoot of sociology in the UK. There used to be a field called leisure studies. I've always thought that was an interesting idea because if you wanted to understand a medium like television, you saw that what it was really was a device for the scheduling of time. It wasn't just to do with its content; it was to do with the way it organized life and how it changed the relation between the amount of time people spend in the home and the amount of time they went out into the public. Some of the concepts that were fundamental to leisure studies were the family and the household, and the life cycle and stage of life. Terribly banal stuff, but actually quite interesting if you contextualise these things. I remember we had a Taiwanese PhD student ages ago who was very excited about piracy and downloading and peer-to-peer sharing - at a moment when Taiwan was very much advanced with respect to all of this technological stuff. He and all his pals at college had been developing systems for pirating and file sharing. But he had trouble with his funding and his doctorate was prolonged much longer than he anticipated. So we said to him, since you've now been doing this research for seven years, why not go back and do another round of interviews and then it can have a longitudinal dimension. It turns out that when he got back from this later round of fieldwork, out of all these young people who had been doing all this kind of fancy sharing and uploading, a significant number of them had now gotten married and had children. And can you guess what they did in the evening? They watched television! Because they'd now come into a stage in their lifecycle when they had less disposable time, so they were looking for a different and more relaxing form of leisure. So that opens up a very interesting problematic that has to do not just with what young people of the rich, North, Western world are doing with their mobile phones or the extent to which that is a model for the rest of the world, but whether it is even a good model for what they themselves are going to do for the rest of their own lives. To think more in terms of the specificities of groups of people and the uses of technologies in particular cultural and social contexts at particular stages of the life cycle to reintroduce that very banal sociological concept.

RN: This seems really interesting when we think about our own practices in carrying out research, and how these are changing in different spheres of academia. What is your take on individual versus group research practice? Are things as you see them becoming more collaborative? Are collaboratively developed methods changing how we conceive of the practice of doing research?

NS: I think it's really necessary to collaborate these days because all of the issues that we are looking at are very complex and we only have a limited set of skills and time available. This becomes very important, but of course the reason why people engage or do not engage in collaborative research is related to age, or academic 
age. There are very contradictory messages that people receive from academia. For example, there is still in many disciplines, including anthropology, this expectation that a doctoral dissertation should be a work of one single scholar - this shows that you are able to do it. And we have had huge discussions within our faculty about the possibility of accepting collaborative $\mathrm{PhD}$ theses. The same goes for publications; you need to have a couple of sole-authored publications that show that you are able to do it on your own. But then on the other hand, within the EU you have these big funding schemes that actually force people to be collaborative whether they like it or not. So now a lot of PhD positions are opening up as part of these larger research projects, and there will be an increasing number of PhDs that will be integrated into broader collaborative research.

DM: One of the premises of collaborative work is often presented as being that it will potentially be good for the field, or good for knowledge. I want to introduce a more personal, more selfish motivation: I like collaborative work because I learn stuff. On my own I've only got my poor thoughts that go around in my own little brain. If you can find people that you can work with over a long term, who ideally have started from some other set of premises with whom you can have convivial disagreement, what could be better than that? All of the things that I've done that were ever worth doing were done in those kind of intellectually agonistic contentions. It's a great way to learn.

HH: I think there are very good reasons why there is a lot of that collaborative group research, and I think it is maybe more accepted in media and communications than it is in, say, anthropology. Why do you think I'm in media and communications department rather than an anthropology one?! My work doesn't quite make sense when seen alongside how anthropologists typically frame their work. There is a kind of call to collaborate but it's complicated. There is a science model for publishing, which is what is being created in work on social media. The country is their responsibility, they sort of own that piece of the pie, but it's coordinated. Still, researchers often don't have questions about whether it's their knowledge - they just have one piece that is what they do. I think that you have a responsibility as a more senior academic to make sure that people you are working with are not just producing work that is in service of what you want to do, but that they are actually doing things that they need to do for their phase of their career, depending on what discipline they are going into. It is important to be sensitive when you are in a position of power in academia. When you collaborate with someone who is a peer, then that is a very different set of collaboration relationships than when it comes to these big EU projects, where it's supposed to be standardised - where there are these small windows of time where you can actually get together and do the kind of thinking you're often doing on your own. I think these are really complicated things and I think there is collaboration during field research, collaboration during analysis, and then collaboration during the writing part - all very different 
ballgames. We have lots of conversations in Sydney about what counts as a contribution. Some projects and some fields like to slap everyone's name on a piece of work, others are very moralistic about it and require that you are involved in the writing, for example, or stipulate that the most senior person on the project has to be the first named. These relationships and practices are very negotiated, and they are the things that we're not supposed to talk about. But these are the issues we need to address.

DM: I think that a really good thing would be to encourage making all of this explicit. Including, for instance, those difficult protocols that are required depending on with whom you are collaborating, what your relation of seniority or juniority is, exactly what kind of recognition should be given in respect to which types of contribution. Because these are all contestable. To let them go on being done by unspoken convention is dangerous. For instance, the notion that books with more than two authors will always be known by whoever has the first alphabetical name, et al., and so on. You know, potentially absurd conventions that can and should be broken up and made explicit.

NS: We have been talking so far only about collaboration among scholars. But now there are increasingly collaborations with industry, civil society actors and so on. And this raises a whole different set of issues which we also need to be thinking about and addressing.

RN: Do you think the study of media in particular somehow lends itself to collaboration outside the academy? Across economic and political interests, say, or in applied contexts? How does the kind of research you all do fit into everyone's favourite grant-writing catchphrase of the moment, "co-production of knowledge"?

DM: That was a question asked with respect to anthropological debates that I came across a while back - this notion of producing a "shared ethnography", by the anthropologist along with his or her subjects. Well, give me a break. No. There is an intellectual responsibility. It may be that I do an ethnography of some family or group. I'll give it to them to read, that's fine. I am interested in what they have to say. But if they say, “No, you've got us wrong," well, ok, but that's just their opinion. I can't be ruled by that. If in my judgement, this is my analysis, and I disagree with what their view of their life is, then I have to take a responsibility to say so: "No, this is what I think." I think it has to be an unavoidable responsibility as the editor or author of a text to say, "Actually no, I am structuring it this way". Of course it's open ended, and of necessity you can read it in other ways. But you can't not offer a perspective. There is one there, so you might as well be explicit about it.

HH: This type of thing can be seen in lot of the things you do regarding interviews and working with people. We have to put in our research ethics forms something 
that says that our subjects have the right to ask us to delete things. I think this is interesting because anthropology probably more than other fields has always grappled with how we represent things. That is actually where the ethical debates and dilemmas are more than about, say, "Can we talk to this person?" Or, "Do they understand that I'm an anthropologist?" That is where that kind of responsibility lies. I think if we are moving into this open-ended, fluid collaboration, then we need to be reflexive about it. There are things that you can get away with saying at a certain stage of your career that you can't get away with saying at other stages of your career.

RN: Are you seeing new and interesting social or cultural phenomena out there that are creating, or requiring, new ways of doing research?

DM: Some of what goes on through putting films and art alongside analytical sessions interests me very much. Towards the end of his career, Stuart Hall spent most of the last years of his life setting up a Black arts and cultural centre in East London and working with filmmakers and photographers. ${ }^{13}$ Some people thought, "Oh he's taken up this kind of hobby". No - this was not at all the way Stuart was thinking about this. His notion was that, having finally gotten a kind of relatively satisfactory conceptual framework with which to think about cultural approaches, he could now do participatory work with people actually making imaginative artwork, and that this would then generate all kinds of questions that he hadn't been able to ask before. And that it would be a way of, as it were, creating new interesting problems - not solutions, but new perspectives on things. I am very interested in that as a possibility. And looking to arts and humanities for other reasons. For instance, alongside ethnography I've found the kind of literary work that Georges Perec and Italo Calvino do extremely interesting on the question of description. ${ }^{14}$ I try to get my students to understand how important description is - the ability to be able to give a precise description of something. Exactitude in description is a terribly difficult thing but a very productive method that we can deploy in relation to all kinds of contemporary problems - to be exact about, for example, how and why a migrant in a particular place is or isn't using a smartphone for which purposes in relation to their sense of dislocation or their attempt to construct a viable future. It's all too easy to make generalisations of such things and not to be exact.

RN: There can also be a tendency to externalize our ability to do research and infuse a given digital device - a camera or a recorder or a smartphone - with the power to capture and produce the perfect description of a given phenomenon or

13 See, e.g. Association of Black Photographers and The Institute of International Visual Arts at Rivington Place (autograph-abp.co.uk; iniva.org).

14 See Calvino (1978; 2009), Perec (1987; 1997 [1973]). 
observation. As though our tools can magically turn the external world into a beautifully penned, well-formulated piece of research. Invest a few hundred Euros in some tech and it's: Presto! Instant results and analysis! This kind of thinking contributes to us losing the facility to be able to write really well or descriptively or even readably.

NS: When I am mentoring students, I don't push them towards using any new methods but rather make them reflect much more on the idea that method is only a way for answering questions. You need to ensure that there is not a perfect, but maybe an almost perfect, match between the methods that you choose and have available, and the kind of questions that you are trying to answer. Because often times, students have a good question but in anthropology the training in methods is in many places lackluster or even absent. And so people will just go off and they say that they do participant observation. And of course the first question to ask is: How do you participate and what exactly do you plan to observe? And that isn't even talking about new methods; that's just talking about tried and true methods, and people just don't think about them. Even if they pay some attention now to data collection methods, it's even worse when it comes to analysis. Once you have this data, what will you do with it? Ahh, yeah, it's ok - a qualitative data analysis programme like NVivo will take care of it. In terms of novelty, if a new method gives an added value to answering questions, then yes of course, we should try it out. But to me the importance is the match between methods and answering questions.

DM: I teach methods to our PhD students in the first year and one of the things I've always found very difficult to deal with is the extent to which their approach is so fashion-driven. I can't seem to get any students now who want to do anything other than what they call "internet ethnography". No one wants to do proper statistical work, or they have some bizarre notion that the algorithms of "big data" will somehow answer their research questions for them. To get them to be seriously pragmatic about methodological choice and to make sure that they are using a method that, while not perfect or good for everything, would be probably the best one for their particular project - that's all I am interested in.

NS: One of the issues I do see with a lot of new methods is that they allow scholars to actually amass a huge amount of data. But what do we do with all this data?

DM: When I worked with Roger Silverstone and Eric Hirsch in the consumer technologies project at Brunel, the project took up an awful lot of public money and in the end it died under the weight of its own data. ${ }^{15}$ We had shelves and shelves of interviews on what at that time were cassette tapes which nobody could cope with.

15 See Silverstone et al. (1992). 
It just died. We'd got all the data, I know some of it was great, but it was too much for us, we couldn't digest it.

HH: I think that anthropology in particular, unlike other disciplines, has found talking about methods kind of vulgar - we are not good at it. I think there are things that students and new projects have to contend with now within the narrow frame of human research subject ethics, that really don't even allow for participant observation or even, at times, interviews. In a certain way this kind of fetishises methods themselves, suggesting that the methods will, in and of themselves, solve everything. I still prefer thinking of methods in terms of materials and what is actually in the field. When Danny [Miller] and I did our contact lists in The Cell Phone, we were trying to track conversations and were finding that every conversation was really short. ${ }^{16}$ So we started going through the lists and we would find out that people were contacting 30 or so people every two weeks and having very short conversations. So the lists sort of evolved through that process, but they were never in our original idea for a methodology. On the one hand planning methods is good because you have to think about some of the issues involved and you have to plan and design your research in a specific way, whereas before you would just go off, participate, observe and talk to people, do interviews and maybe take some pictures - these were the kind of the tools we were told to work with. I have a hard time thinking of the methods I use as particularly new but more sort of adaptations of things that you kind of customise to the particular context. We did this portable kit study that built on stuff that Mizuko Ito, Daisuke Okabe and Ken Anderson did in Tokyo, LA and London, and in order to bring it to the border of Haiti and the Dominican Republic just required a different set of questions. ${ }^{17}$ So that's the kind of fun and playful sort of methods work that I like to get involved in. And I think that that kind of creativity is productive.

DM: I think there is a lot to be said for some things that don't even seem like methods. There was a great incident with a very conventional literary-trained film scholar who was important in Britain in the 1950 s and 6os called Victor Perkins who worked at Warwick University. ${ }^{18}$ He was thought of by some of the younger, "hip" scholars as sort of a rather staid old dude. But he was great. He was at a conference once, and he was giving his analysis of a particular film. And somebody with their methodological hat on asked him sternly, "But what is your methodology?" And Victor paused for a moment. And then he said, "Looking. And thinking”. He was dead serious. Because if you asked him about a film, he could tell you exactly where the camera shots were, how many cuts there were in a scene, how the lighting changed between this scene and another scene, which scene was

16 See Horst/Miller (2006).

17 Ito et al. (2009).

18 See, e.g. Perkins (1993). 
shown from which character's perspective, etc. He really looked. That was also very good pedagogy. So they instituted a thing at Warwick whereby students, when they were studying a film, weren't allowed to say anything about it until they'd seen it at least twice, preferably three times. Absolute simplicity, but it made them look. And what are we all doing? We're trying to look, and think carefully.

HH: The best class I ever took was a critical ethnographies course. We read five ethnographies over a period of ten weeks. We read each book once. We read it again. And then we read it a third time. And we had to go through and consider: here are the questions being asked, so what methods did they use and what evidence can you actually see and pull out? And you had to really know the text to be able to go in there and do that. It was the best class - and it was just five books! That sort of thinking, really looking at how people pull these arguments together; that is such a valuable thing. And a lot of it is based on just writing field notes. You don't have to archive this or input that.

NS: I have to say that I was kind of lucky. When I was a graduate student in the USA I took one of the boot camps organized by the US National Science Foundation. Basically, for three weeks you are put on an island, you are totally isolated, there is no television, nothing. You have three weeks to design and develop your own research project. You have all sorts of scholars with different kinds of expertise who then constantly question you and make you reflect on how to maybe rephrase your questions, or look at a question and see that it's interesting but actually impossible to answer. And you also have to narrow down your focus, since often times our questions are very broad and need narrowing down to something that is manageable.

RN: I completely agree with the importance of starting with big questions and honing your research context by narrowing down what you're actually looking at - this is a great formula for planning effective research. ${ }^{19}$ Sometimes we feel compelled to squeeze every idea we have into one project or paper because of this pressure many of us feel to produce and say something. David, you have spoken about the importance of slowing down at a time when speed seems to be the order of the day. There are questions surrounding who has the privilege of slowing down; not everyone is able to do so. If we are to take seriously your encouragement to slow down and pace ourselves, what sort of advice would you give to scholars of media whose work can often be studied from anywhere and at any time, 24-7? The pressures of academia can make it hard for many to manage the balancing act of life - many of us have personal experience of this. What would you say to early-career scholars of media who are looking to make it, and to make a name for themselves?

19 See Eriksen (2001). 
DM: Instrumentally, I would advise them to choose a fairly narrow topic and write a monograph on one specific thing. So at least they can get known for having a unique value proposition. I mean, that's marketing talk, but it is probably still the best thing to do, in terms of career advice. It's very depressing to say that, but that's still it. Bury yourself in a lot of interesting collective projects? Hmmm, you'll probably have an interesting life, but will you have a job in ten years' time? If you've always been a researcher on this and a helper on that and collaborator on the other, it will be harder to get a full-time permanent job, supposing there are any. Alternatively, hope like hell that we're more successful in arguing for the recognition of individual contributions to collective projects. Because as it stands, academia is in large part an incredibly traditionalist, old-fashioned business that trades on that currency of expertise on a single topic as expressed in the publication of a monograph.

NS: Unfortunately, academia as a whole is incredibly traditional and certainly the people who hold power are extremely traditional. I myself have been a kind of a rebel, so my advice might not be the best. But my own take on this is that I am still in academia because I can do the things that I like. The day that will become impossible, then I will leave academia because I am not married to it. I am here because I have a certain passion for science and for doing the things I am doing, and as long as that remains possible then I'll keep at it. Some of the advice I give younger scholars is that yes, there are all these rules and regulations, but I always tell them they don't need to follow the rules blindly but use them strategically. This is particularly important when you are mobile and you move from one academic culture to another because even every university has a different culture, different expectations and different rules. Be very strategic, and that means making choices and probably also limiting your focus. But the passion always needs to be there. If you bring no passion to academia, you will become extremely frustrated, especially these days. The passion is also to a certain extent responsible for the state that we are in. It's because academics have accepted a lot of stuff being thrown at them because they were so passionate about their science that they agreed to take on all these other, related administrative duties. It's very unfortunate.

HH: I have had a very unusual, non-traditional past. But the first thing I would say is that there are some strong benefits to doing your project alongside or in concert with a related, larger project, and there is an inherent collaborative nature to those bigger projects. But make sure that your own project has its own integrity. Those are hard things to find, but when those opportunities appear they should really be driven by your own passion for things. There was one point at which I was thinking for my doctoral project of studying in India and looking at return migrants. And I went to India and realized that I would have been quite constrained if I were to pursue the project that I really wanted to do there. At that point I had been talking to a friend who suggested I consider Jamaica. But my 
supervisor told me that you can't really make a career out of studying in the Caribbean, "I've never seen a successful academic study in the Caribbean," he told me. “Why don't you go to Europe?” But that wasn't what I was passionate about. I think that at the beginning of an academic career, there is always this thing of wanting to stake your claim and wanting to be doing all the innovative things. But at the core of it, you have to be passionate about what you're doing because it defines you for, probably, eight to ten years. So you always have to start with a passion, but I do think that there are opportunities that can crop up related to larger projects. But you have to understand what you're getting yourself into.

\section{References}

Appadurai, Arjun (ed.) (1986): The social life of things. Commodities in cultural perspective, Cambridge: Cambridge Univ. Press.

Bausinger, Hermann (1990 [1961]): Folk culture in a world of technology, Indianapolis: Indiana University Press.

Calvino, Italo (1978): Invisible cities, New York: Harcourt Brace Jovanovich.

Calvino, Italo (2009): Our ancestors, New York: Vintage Books.

Eriksen, Thomas H. (2001): Small places, large issues: An Introduction to Social and Cultural Anthropology, London: Pluto Press.

Gell, Alfred (1986): "Newcomers to the world of goods: consumption among the Muria Gonds.”. In: Arjun Appadurai (ed.), The Social life of things: Commodities in cultural perspectives, Cambridge: Cambridge Univ. Press.

Gell, Alfred (1998): Art and agency: An Anthropological Theory, Oxford: Clarendon Press.

Horst, Heather A./Miller, Daniel (2006): The cell phone: An anthropology of communication, Oxford: Berg.

Horst, Heather A./Miller, Daniel (2012): Digital anthropology, Oxford: Berg.

Ito, Mimi/Okabe, Daisuke/Anderson, Ken (2009): "Portable objects in three global cities: The personalization of urban places." In: Rich Ling/Scott Campbell (eds.), The reconstruction of space and time: mobile communication practices, London: Routledge.

Morley, David (2017): Communications and mobility. The migrant, the mobile phone, and the container box, Hoboken NJ: John Wiley \& Sons, Inc.

Nilsson, Jessika/Salazar, Noel B. (2017): "Embedded and re-purposed technologies: Human mobility practices in Maasailand.” In: Mobilities 12/3, pp. 445461.

Perec, Georges (1987): Life, a user's manual, Boston: David R. Godine.

Perec, Georges (1997[1973]): “Approaches to what?” In: Species of spaces and other pieces, Harmondsworth: Penguin.

Perkins Victor F. (1993): Film as film: Understanding and judging movies, Cambridge: Da Capo Press. 
Pink, Sarah/Horst, Heather/Postill, John/Hjorth, Larissa/Lewis, Tania/Tacchi, Jo (2016): Digital ethnography: Principles and practice, London: Sage.

Salazar, Noel B./Coates, Jamie (2017): “Key figures of mobility”. In: Social Anthropology 25/1, Theme issue.

Salazar, Noel B./Jayaram, Kiran (2016): Keywords of mobility: Critical engagements, Oxford: Berghahn.

Seiter, Ellen/Borchers, Hans/Kreutzner, Gabriele/Warth, Eva-Maria (1991): “'Don't treat us like we're so stupid and naïve': Toward an ethnography of soap opera viewers.” In: Ellen Seiter/Hans Borchers/Gabriele Kreutzner/Eva-Maria Warth (eds.), Remote control: Television, audiences and cultural power, London: Routledge.

Silverstone, Roger/Hirsch, Eric/Morley, David (1992): "Information and communication technologies and the moral economy of the household.” In: Roger Silverstone/Eric Hirsch (eds.), Consuming technologies: Media and information in domestic spaces, London: Routledge.

Spigel, Lynn (2004): “Introduction”. In: Lynn Spigel/Jan Olsson (eds.), Television after TV, Durham: Duke University Press. 
